\title{
Pengembangan Bahan Ajar Tematik Berbasis Nilai-Nilai Keislaman Kelas VI Madrasah Ibtidaiyah
}

\author{
Sumining \\ MIN 2 Jember \\ suminings@gmail.com \\ DOI:10.35719/educare.v2i1.30
}

\begin{abstract}
Development of thematic teaching materials based on Islamic values, especially those related to the contents of the verses of the Alqur'an and / or hadith as the basis of all science. In the available books, there are no thematic teaching materials that are integrated with the Al-Quran and Hadith, as well as Islamic values that are able to implement the core competencies of the 2013 curriculum, namely the competence of spiritual attitudes in thematic learning. The formulation of this research is: (1) producing thematic teaching materials based on Islamic values theme 7 (Leadership) class 6 Madrasah Ibtidaiyah Negeri 2 Jember. (2) to determine the effectiveness of thematic teaching materials based on Islamic values in learning. This study uses a research and development research type, the Borg and Gall model which is divided into 10 steps, namely: (1) research and data collection (2) planning, (3) product draft development, (4) initial field trials, ( 5) revising the results of trials, (6) field trials, (7) improving products from field tests, (8) conducting field trials, (9) improving product results, and (10) disseminating and implementing. The testing technique was carried out by comparing the pre-test and post-test values. The data was calculated using the t-test and processed using the SPSS application to determine the effectiveness of teaching materials. The results of this study indicate: the validation test produces an average of $88.79 \%$ with the criteria that the book is very suitable for use in learning. In terms of attractiveness, this book is very interesting to use for students, this is based on the results of the questionnaire data given to students with an average of $88.24 \%$ with very attractive qualifications. Meanwhile, from the results of the pre-test and post-test based on the t count which shows that it is greater than the t table, it means that the book is effective for use in learning.
\end{abstract}

Keywords: Teaching Materials; Thematic Learning; Islamic Value 


\begin{abstract}
Abstrak
Pengembangan bahan ajar tematik berbasis nilai keislaman, terutama yang terkait dengan isi ayat Alqur'an dan/atau hadits sebagai dasar dari semua sains. Dalam buku yang telah tersedia tidak ada bahan ajar tematik yang terintegrasi dengan Al-Quran dan Hadits serta nilai-nilai Islam yang mampu mengimplementasikan kompetensi inti dari kurikulum 2013 yaitu kompetensi sikap spiritual dalam pembelajaran tematik. Perumusan penelitian ini yaitu: (1) menghasilkan bahan ajar tematik berbasis nilai keislaman tema 7 (Kepemimpinan) kelas 6 Madrasah Ibtidaiyah Negeri 2 Jember. (2) mengetahui efektifitas bahan ajar tematik berbasis nilai-nilai keislaman dalam pembelajaran. Penelitian ini menggunakan jenis penelitian pengembangan Research and Development, model Borg and Gall yang terbagi menjadi 10 langkah, yaitu: (1) penelitian dan pengumpulan data(2) perencanaan, (3) pengembangan draf produk, (4) uji coba lapangan awal, (5) merevisi hasil uji coba, (6) uji coba lapangan, (7) penyempurnaan produk hasil uji lapangan, (8) uji pelaksanaan lapangan, (9) penyempurnaan produk hasil, dan(10) diseminasi dan implementasi. Teknik uji coba dilakukan dengan cara membandingkan nilai pre-test dan post-test. Data dihitung dengan uji-t dan diolah menggunakan aplikasi SPSS untuk mengetahui efektifitas bahan ajar. Hasil penelitian ini menunjukkan bahwa uji validasi rata-rata menghasilkan $88,79 \%$ dengan kriteria bahwa buku tersebut sangat layak untuk digunakan dalam pembelajaran. Dari segi kemenarikan, buku ini sangat menarik untuk digunakan peserta didik, hal ini berdasarkan hasil data angket yang diberikan kepada peserta didik rata-rata $88,24 \%$ dengan kualifikasi sangat menarik. Sedangkan dari hasil pre-test dan pos-test berdasarkan uji t menunjukan lebih besar dari t tabel, berarti buku tersebut efektif untuk digunakan dalam pembelajaran.
\end{abstract}

Kata Kunci: Bahan Ajar; Pembelajaran Tematik; Nilai Keislaman

\title{
PENDAHULUAN
}

Pembelajaran tematik sebelumnya hanya digunakan di Taman Kanakkanak saja, karena dianggap bahwa Taman Kanak-kanak (TK) merupakan pendidikan pra sekolah yang bertujuan untuk mempersiapkan diri ketika nanti masuk ke sekolah dasar, sehingga dalam pembelajaran TK dibuat fleksibel dalam mengelola waktu, pada pengelompokan dan pembelajaran terpadu berguna untuk mempersiapkan diri memasuki sekolah dasar. Seperti yang dikemukakan oleh Valerica Anghelache sebagai berikut: 
"The new design of planning the activities in the kindergarten allows flexibility in managing the time spent in school and students grouping. Also, the integrated activities prepare the child for the interdisciplinary teachinglearning of knowledge in primary school". ${ }^{.}$

Penetapan pendekatan tematik dalam pembelajaran di kelas rendah oleh Badan Standar Nasional Pendidikan (BSNP) tidak lepas dari perkembangan konsep dari pendekatan terpadu itu sendiri, dan pembelajaran tematik terpadu yang dipelajari dan dikembangkan di Indonesia berdasarkan model yang dikemukakan oleh Forgety berawal dari konsep yang dikembangkan oleh Jakob. ${ }^{2}$ Sekarang pembelajaran tematik tidak hanya digunakan di TK ataupun kelas rendah saja, namun juga dilaksanakan di sekolah tingkat dasar mulai kelas 1 sampai kelas 6, dengan harapan dapatmeningkatkan mutu pendidikan di Indonesia.

Kurikulum 2013 yang kental dengan pembelajaran tematik terus mengalami perbaikan, sehingga beberapa kali mengalami revisi, mulai dari integrasi antar mata pelajaran, Kompetensi Dasar, sampai pada bahan ajar yang digunakan. Bahkan implementasi kompetensi inti satu dan dua yang tadinya dimasukkan dalam semua mata pelajaran, pada akhirnya hanya dimasukkan dalam mata pelajaran PKn dan Agama.

Pembelajaran tematik sangat penting diterapkan di sekolah dasar, sebab memiliki banyak nilai dan manfaat, diantaranya: (1) Dengan menggabungkan beberapa KD dan indikator serta isi mata pelajaran akan terjadi penghematan, karena tumpang tindih materi dapat dikurangi bahkan dihilangkan, (2) peserta didik dapat melihat hubungan-hubungan yang bermakna sebab isi/materi pembelajaran lebih berperan sebagai sarana atau alat, bukan tujuan akhir, (3) pembelajaran tidak terpecah-pecah karena

1 Valerica Anghelachea \& Cristina Corina Ben, Integrated Teaching The New Curricular Design Of Pre-Primary educational System In Romania, Procedia Social and Behavioral Sciences, 51: (2012), 129.

${ }^{2}$ Abdul Majid, Pembelajaran Tematik Terpadu, (Bandung: Remaja Rosdakarya, 2017), 80 . 
peserta didik dilengkapi dengan pengalaman belajar yang lebih terpadu sehingga akan mendapat pengertian mengenai proses dan materi yang lebih terpadu juga, (4) memberikan penerapan-penerapan dari dunia nyata sehingga dapat mempertinggi kesempatan transfer belajar, (5) dengan adanya pemaduan antarmata pelajaran maka penguasaan materi pembelajaran akan semakin baik dan meningkat. ${ }^{3}$ Jadi pembelajaran tematik begitu penting diterapkan di sekolah dasar karena mempunyai banyak nilai dan manfaat bagi peserta didik.

Beberapa sekolah, baik di tingkat dasar maupun di tingkat lanjutan banyak mengadakan kegiatan yang bernafaskan religius, dengan maksud menanamkan nilai-nilai religi pada peserta didik. Fenomena ini semakin marak sehubungan dengan semakin banyak peserta didik yang mulai meninggalkan nilai-nilai agama dalam perilakunya. Selain kegiatan-kegiatan yang bernafaskan religius, tentu dibutuhkan juga bahan ajar tematik yang berbasis nilai-nilai keislaman, terutama untuk sekolah pada tingkat dasar, karena anak usia sekolah dasar merupakan usia yang sangat diperlukan penanaman nilai-nilai religius sebagai pondasi pribadinya, terutama nilai keimanan.

Penanaman nilai keimanan merupakan tugas orang tua, peran orang tua sangat berpengaruh bagi tingkat keimanan anak, melalui bimbingan orang tua membantu anak untuk mengenal siapa Tuhannya, sifat-sifat Tuhan, bagaimana kewajiban manusia terhadap Tuhan. Dalam Al-Qur'an juga dijelaskan dalam surat Luqman ayat 13:

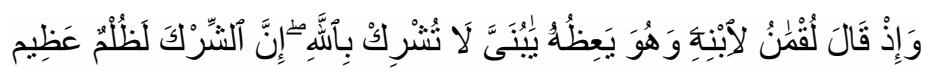

Atinya: "Dan (ingatlah) ketika Luqman berkata kepada anaknya, di waktu ia memberi pelajaran kepada anaknya: "Wahai anakku, Janganlah engkau mempersekutukan Allah, sesungguhnya mempersekutukan Dia (Allah) adalah kedzaliman yang besar”. (QS. Luqman:13). ${ }^{4}$

\footnotetext{
${ }^{3}$ Rusman, Pembelajaran Tematik Terpadu Teori, Praktik dan Penilaian, (Jakarta: Raja Grafindo Persada, 2015), 153.

${ }^{4}$ Kementrian Agama RI, Al-Qur"an dan Tafsirnya Jilid VII, 19-20- 21, (Jakarta: Lentera Abadi, 2010 ), 549.
} 
Pendidikan anak sekarang ini tidak hanya tanggung jawab orang tua, tetapi juga tanggung jawab lembaga pendidikan baik formal maupun non formal, sehingga guru atau tenaga pendidik secara otomatis memegang tanggung jawab tersebut. Karena sebagian waktu anak berada di sekolah dan bersama guru, maka penanaman nilai keimanan atau keislaman juga tanggung jawab guru. Disinilah pentingnya penggunaan bahan ajar yang tepat untuk membantu guru dalam melaksanakan tugasnya.

Penanaman nilai ibadah pada anak usia dini dimulai dari dalam keluarga. Karena anak yang masih kecil lebih menyukai kegiatan-kegiatan ibadah yang nyata seperti melaksanakan sholat. Kegiatan ibadah tidak hanya diajarkan oleh keluarga, namun juga diajarkan di sekolah, baik secara teori maupun praktik Sebagaimana hadist Nabi Muhammad SAW. Yang diriwayatkan oleh Abu Dawud: "Dari Abdul Malik bin Rabi" bin Sabrah dari ayah nya dari kakeknya, yaitu Sabrah bin Ma"bad Al Juhni R.A. Dia berkata: Nabi SAW. Bersabda: "Suruhlah anak-anak mengerjakan shalat, apabila telah berumur tujuh tahun, dan pukullah dia karena meninggalkannya apabila telah berumur sepuluh tahun”. Hadis ini juga dikeluarkan oleh Tirmidzi dan katanya: Hadis Hasan Shahih. (H.R. Abu Dawud). ${ }^{5}$

Berdasarkan hadis tersebut, menjalankan ibadah harus ditanamkan sejak dini, walaupun usianya belum baligh. Dengan kebiasaan yang dilakukan setiap hari sejak kecil secara terus menerus, diharapkan menjadi kebiasaan yang akan selalu dilakukan dan tidak ditinggalkan. Pembelajaran di tingkat dasar menggunakan pendekatan pembelajaran tematik dan itu merupakan kebutuhan bagi peserta didik Sekolah Dasar/Madrasah Ibtidaiyah, dengan alasan sebagai berikut: pertama, peserta didik SD/MI secara psikologi sedang memasuki tahap perkembangan kognisi “operasional kongkret; kedua, pembelajaran yang efektif dan berhasil adalah

\footnotetext{
${ }^{5}$ Bey Arifin, Tarjamah Sunan Abi Daud, (Semarang: Asy Syifa,tt). 325.
} 
yang bermakna bagi peserta didik, jadi bukan sekedar menghafal; ketiga, telah terjadi pergantian kurikulum dari KTSP ke kurikulum 2013 yang sangat kental dengan nuansa pembelajaran tematik; keempat, guna menciptakan proses pembelajaran agar lebih efektif. ${ }^{6}$ Anak usia sekolah dasar memiliki kecenderungan berfikir secara holistik, sehingga pembelajaran tematik akan membantu perkembangan intelektual dan sosial anak.

Dalam kurikulum 2013 pendekatan tematik integratif ini bertujuan meningkatkan mutu pendidikan dalam membentuk budi pekerti dan akhlak mulia secara utuh, terpadu, dan seimbang sesuai dengan Standar Kompetensi Lulusan (SKL) pada setiap satuan pendidikan, karena itu dalam implementasinya diharapkan peserta didik mampu secara mandiri meningkatkan dan menggunakan pengetahuannya sesuai dengan nilai-nilai karakter dan akhlak mulia dalam kehidupan sehari-hari. Salah satu pendidikan karakter yang diharapkan adalah sikap religius, hal ini dimaksudkan agar peserta didik mempunyai jiwa yang kokoh dalam menghadapi dampak negatif dari perkembangan era globalisasi yang tentunya mudah mempengaruhi gaya hidup mereka, terutama anak usia sekolah dasar yang memiliki kecenderungan untuk serba ingin tahu.

Untuk mewujudkan hal tersebut maka dalam implementasi kurikulum 2013, guru harus mendidik dengan baik dan benar, karena guru adalah pendidik, yang menjadi tokoh, panutanbagi para peserta didik dan lingkungannya. Oleh karena itu, guru harus memiliki standar kualitas pribadi tertentu, sehingga memiliki tanggung jawab, berwibawa, mandiri, dan disiplin dalam melaksanakan tugas profesinya. Sedangkan berkaitan dengan tanggung jawabnya guru harus mengetahui dan memahami nilai,

\footnotetext{
${ }^{6}$ Andi Prastowo, Pengembangan Bahan Ajar Tematik Tinjauan Teoritis dan Praktis,(Jakarta: Kencana Prenadamedia Group, 2014), 32.
} 
norma moral, dan sosial, serta berusaha berperilaku dan berbuat sesuai nilai dan norma tersebut. ${ }^{7}$

Tentu untuk mendukung tugas guru tersebut dibutuhkan bahan ajar yang relevan dan mengandung nilai dan norma yang harus ditanamkan kepada peserta didik sedini mungkin, tidak hanya tersirat tetapi juga harus tersurat didalam bahan ajar yang digunakan dalam pendidikan Sekolah Dasar/ Madrasah Ibtidaiyah. Pembelajaran tematik belum cukup apabila hanya menggunakan buku guru dan buku peserta didik saja. Dalam pembelajaran, guru seharusnya memberikan kesempatan kepada peserta didik untuk menerima dan mengembangkan nilai-nilai keislaman dan belajar lebih aktif dalam setiap pembelajaran. Guru harus dapat membimbing dan mengarahkan kegiatan belajar sesuai dengan tujuan pembelajaran yang bermakna, termasuk dalam perilaku sehari-hari yang mencerminkan sikap religius. Kondisi seperti ini akan merubah kegiatan belajar mengajar dari teacher oriented menjadi student oriented.

Landasan utama mengapa nilai-nilai keagamaan dimasukkan ke dalam pendidikan. Pertama, UUD 1945 (versi Amendemen), Pasal 31, ayat 3 menyebutkan, "Pemerintah mengusahakan dan menyelenggarakan satu sistem pendidikan nasional, yang meningkatkan keimanan dan ketakwaan serta ahlak mulia dalam rangka mencerdaskan kehidupan bangsa, yang diatur dengan undang-undang." ${ }^{8}$ Kedua, dalam pasal 31 ayat 5, menyebutkan bahwa "Pemerintah memajukan ilmu pengetahuan dan teknologi dengan menjunjung tinggi nilai-nilai agama dan persatuan bangsa untuk kemajuan peradaban serta kesejahteraan umat manusia." Pasal tersebut mengisyaratkan bahwa integrasi nilai-nilai keagamaan dalam pembelajaran sangatlah penting untuk mewujudkan amanah konstitusi tersebut.

\footnotetext{
${ }^{7}$ Mulyasa, Guru dalam Implememtasi Kurikulum 2013 (Bandung: PT Remaja Rosdakarya, 2014), 54

${ }^{8}$ UUD 1945, Hasil Amandemen ke-IV Tahun 2002 (Surakarta: Al-Hikmah, 2002), 24.

${ }^{9}$ UUD 1945, Hasil ...., 25.
} 
Dalam Undang-Undang Nomor 20 tahun 2003 tentang Sistem Pendidikan Nasional Pasal 3 menyebutkan bahwa, tujuan pendidikan nasional adalah mengembangkan potensi peserta didik agar menjadi manusia yang beriman dan bertakwa kepada Tuhan Yang Maha Esa, berakhlak mulia, sehat, berilmu, cakap, kreatif, mandiri, dan menjadi warga negara yang demokratis serta bertanggung jawab. ${ }^{10}$ Untuk mewujudkan tujuan pendidikan nasional tersebut, maka peran seorang guru sangatlah penting, dengan berbagai cara dilakukan, salah satunya adalah mengembangkan bahan ajar yang mengandung nilai-nilai keagamaan, karena dalam nilai-nilai keagamaan terkandung semua hal yang diharapkan dalam tujuan pendidikan nasional tersebut.

Bahan ajar tematik berbasis nilai-nilai keislaman belum banyak tersedia, maka disinilah perlu dikembangkan bahan ajar yang diintegrasikan dengan nilai agama Islam sebagai pedoman hidup sehari-hari, karena dalam bahan ajar tersebut akan memadukan atau menghubungkan materi pembelajaran dengan dalil-dalil Al-Quran dan Hadits, serta gambar-gambar islami yang mendukung dengan tujuan meningkatkan religius peserta didik dan penanaman nilai-nilai keislaman, dengan harapan dapat diimplementasikan dalam kehidupan sehari-hari.

Bahan ajar tematik berbasis nilai-nilai keislaman selain berisi materi pelajaran sesuai Kompetensi Dasar yang terdapat dalam kurikulum 2013 juga berisi ayat Al-Qur'an, Hadis, dan gambar, serta cerita-cerita islami yang relevan dengan materi yang ada. Dengan gambar yang berwarna dan menarik diharapkan dapat memberikan stimulus kepada peserta didik untuk lebih senang mempelajari buku ini, dengan harapan tujuan pembelajaran dapat tercapai dengan maksimal.

Bahan ajar ini ditujukan untuk peserta didik kelas VI Madrasah Ibtidaiyah Negeri 2 Jember, karena madrasah sangat kental dengan nuansa

\footnotetext{
${ }^{10}$ UU RI No. 20 Tahun 2003 Tentang Sistem Pendidikan Nasional (Jakarta: Sinar Grafika, 2003), 3.
} 
islami dan seluruh peserta didiknya beragama Islam, sehingga bahan ajar ini akan sangat cocok dan sesuai. Lembaga ini juga membutuhkan bahan ajar tematik yang berbasis nilai keislaman untuk mendukung berbagai program dalam menanamkan nilai religius pada peserta didik, selain dalam bentuk kegiatan pengembangan diri. Inti permasalahan dari penelitian ini adalah belum banyak tersedianya bahan ajar tematik yang berbasis nilai-nilai keislaman. Bahan ajar berbasis nilai-nilai keislaman sangat dibutuhkan di Madrasah Ibtidaiyah Negeri 2 Jember karena penanaman nilai-nilai keislaman tidak hanya dilakukan pada saat pembelajaran bidang studi agama Islam saja, namun harusnya juga dilakukan pada setiap pembelajaran bidang studi apapun. Ini juga berkaitan dengan program Gerakan Membangun Madrasah, dimana semua kegiatan harus bercirikan madrasah yaitu bernuansa islami. ${ }^{11}$ Melihat dari fenomena-fenomena dan permasalahan di atas, maka peneliti tertarik untuk mengembangkan bahan ajar tematik berbasis nilai-nilai keislaman sekaligus meneliti kelayakan dari segi materi, bahasa, dan desain dari bahan ajar tersebut.

\section{METODE PENELITIAN}

Metode penelitian yang digunakanadalah model Research and Development (R\&D) Borg dan Gall. Penelitian Pengembangan tersebut memiliki langkah-langkah berikut: ${ }^{12}$ Research and Information Collecting (penelitian dan pengumpulan informasi), Planning (melakukan perencanaan), Develop Preliminary Form of Product (pengembangan produk awal), Preliminary Field Testing (Uji coba lapangan awal), Main Product Revision (Merevisi hasil uji coba), Main Field Testing (Uji coba lapangan), Operational Product Revision (melakukan revisi terhadap produk). Operational Field Testing (Uji lapangan operasional), Final Product Revision (Revisi produk akhir), Dissemination and Implementation

\footnotetext{
${ }^{11}$ Hindanah, Wawancara, Jember 4 September 2019.

${ }^{12}$ Sugiyono, Metode Penelitian dan Pengembangan research and development,(Bandung: ALFABETA,. 2015), 35-36.
} 
(Diseminasi dan implementasi produk). Pada uji coba produk kali ini dilakukan secara daring, karena pada situasi pandemi covid 19, peserta didik sedang dalam keadaaan belajar di rumah, sehingga peneliti melakukan kegiatan pre-test dan post-test secara daring melalui aplikasi google form.

\section{HASIL DAN PEMBAHASAN TEMUAN}

\section{Hasil Validasi Ahli Materi/Isi}

Validasi materi/isi dilakukan dengan tujuan untuk mengetahui kesesuaian dan ketepatan materi/isi bahan ajar yang dikembangkan dengan kurikulum yang berlaku, dengan segala ketentuannya dan kesesuaian dengan kebutuhan di tempat penelitian.

Ahli materi/isi yang menvalidasi bahan ajar ini adalah Dr. Erma Fatmawati, S.Ag, M.Pd.I. Beliau adalah dosen Pendidikan Guru Agama Islam Pascasarjana IAIN Jember sekaligus sebagai Kepala Sub Bagian Tata Usaha Kantor Kementrian Agama Kabupaten Jember. Sebelumnya Beliau pernah menjadi guru di MIN 3 Jember dan Kepala MIN 4 Jember.Penilaian ahli materi/isi terdiri dari dua aspek, yaitu aspek pembelajaran dan aspek isi. Aspek pembelajaran terdiri dari 10 indikator dan aspek isi terdiri dari 7 indikator, sehingga kalau dijumlahkan semua terdiri dari 17 indikator. Setiap indikator memiliki skor 1-5. Data hasil validasi dari ahli materi/isi dapat dilihat pada tabel 4.1 berikut.

Tabel 4.1

Hasil Validasi Ahli Materi

\begin{tabular}{|c|c|c|c|c|c|c|c|}
\hline \multirow{2}{*}{ No } & \multirow{2}{*}{ Indikator } & \multicolumn{5}{|c|}{ Skor Penilaian } & \multirow{2}{*}{$\%$} \\
\hline & & 1 & 2 & 3 & 4 & 5 & \\
\hline \multicolumn{8}{|c|}{ Aspek pembelajaran } \\
\hline 1 & $\begin{array}{l}\text { Kesesuaian buku dengan kurikulum } \\
2013\end{array}$ & & & & $\sqrt{ }$ & & $80 \%$ \\
\hline 2 & $\begin{array}{l}\text { Kesesuaian Kompetensi Inti, } \\
\text { Kompetensi Dasar dengan indikator }\end{array}$ & & & & $\sqrt{ }$ & & $80 \%$ \\
\hline 3 & $\begin{array}{l}\text { Kesesuaian materi dengan Kompetensi } \\
\text { Dasar dan indicator }\end{array}$ & & & & $\sqrt{ }$ & & $80 \%$ \\
\hline 4 & Keterpaduan antar mata mata pelajaran & & & & & $\sqrt{ }$ & $100 \%$ \\
\hline 5 & Sistematika penyajian materi & & & & & $\sqrt{ }$ & $100 \%$ \\
\hline 6 & $\begin{array}{l}\text { Kejelasan fakta, konsep, prinsip, dan } \\
\text { prosedur }\end{array}$ & & & & & $\sqrt{ }$ & $100 \%$ \\
\hline
\end{tabular}




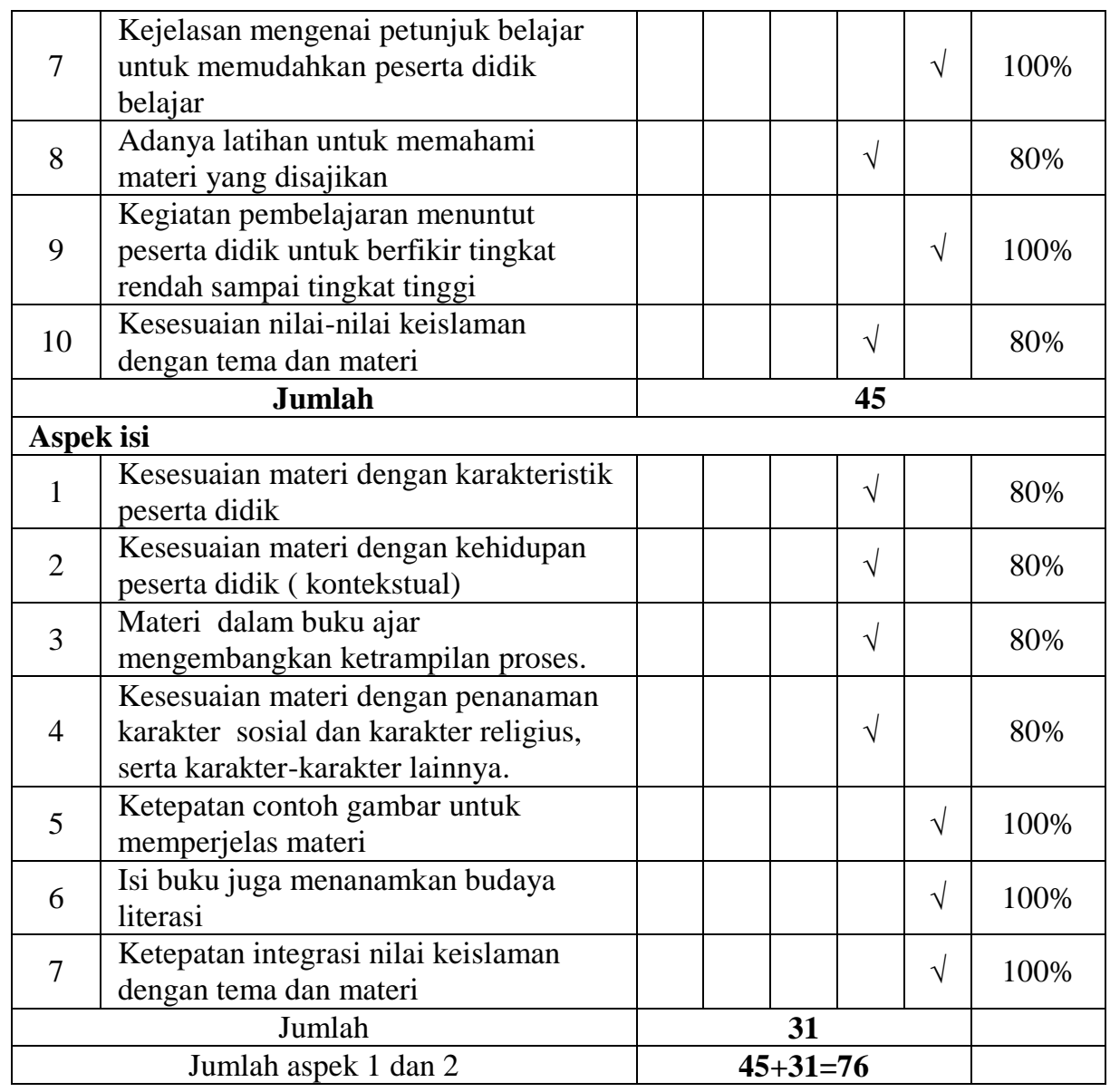

Berdasarkan hasil validasi ahli materi yang terdapat pada tabel 4.1, maka persentase tingkat kelayakan dapat dihitung menggunakan rumus sebagai berikut:

$$
\mathbf{P}=\frac{f}{N} \times 100 \%
$$

\section{Keterangan:}

$$
\begin{aligned}
& \mathrm{P}=\text { Angka persentase data angket } \\
& F=\text { Jumlah skor yang diperoleh } \\
& \mathrm{N}=\text { Jumlah skor maksimum } \\
& \mathbf{P}=\frac{76}{85} \times 100 \% \\
& \mathrm{P}=89,41 \%
\end{aligned}
$$

Dari perhitungan tersebut diperoleh data presentasi tingkat kelayakan bahan ajar dari segi mater/isi sebesar 89,41\%. Berdasarkan tabel interpresentasi kelayakan, bahan ajar tematik berbasis nilai-nilai keislaman 
dinyatakan sangat layak dari segi materi/isi, karena nilai validasi yang diperoleh dari ahli materi/isi adalah $89,41 \%$, sehingga bahan ajar tersebut siap digunakan untuk kegiatan pembelajaran.

Adapun komentar yang diberikan oleh ahli materi yaitu bahwa buku sudah sesuai dengan KD yang telah ditetapkan, pengembangan materi sudah sesuai dengan tema dan cukup luas, diharapkan bahan ajar ini bisa digunakan dilembaga tempat penelitian dan lembaga lain yang sederajat.

\section{Hasil Validasi Ahli Bahasa}

Validasi bahasa bertujuan untuk mengetahui ketepatan bahasa yang digunakan dalam bahan ajar yang dikembangkan. Apakah bahasa yang digunakan sudah sesuai dengan kaidah Bahasa Indonesia yang baik dan benar dan dapat dipahami dengan mudah oleh peserta didik. Validasi bahasa dilakukan oleh Shidiq Ardianta, M.Pd. beliau adalah seorang dosen IAIN Jember.

Penilaian ahli bahasa teridiri dari dua aspek yaitu, aspek keterbacaan dan aspek tata bahasa. Aspek keterbacaan terdiri dari 5 indikator dan aspek tata bahasa terdiri dari 5 indikator juga, sehingga kalau dijumlahkan terdiri dari 10 indikator dengan skor 1-5. Data hasil validasi ahli bahasa dapat dilihat pada tabel 4.2 berikut:

Tabel 4.2

Hasil Validasi Ahli Bahasa

\begin{tabular}{|c|c|c|c|c|c|c|c|}
\hline \multirow{2}{*}{ No } & \multirow{2}{*}{ Indikator } & \multicolumn{5}{|c|}{ Skor Penilaian } & \multirow{2}{*}{$\%$} \\
\hline & & 1 & 2 & 3 & 4 & 5 & \\
\hline \multicolumn{8}{|c|}{ Aspek Keterbacaan } \\
\hline 1 & Kejelasan informasi & & & & $\sqrt{ }$ & & $80 \%$ \\
\hline 2 & Menggunakan bahasa yang komunikatif & & & & & $\sqrt{ }$ & $100 \%$ \\
\hline 3 & $\begin{array}{l}\text { Bahasa dalam buku sesuai dengan tahap } \\
\text { perkembangan peserta didik }\end{array}$ & & & & & $\sqrt{ }$ & $100 \%$ \\
\hline 4 & Kesesuaian pilihan jenis dan ukuran huruf & & & & & $\sqrt{ }$ & $100 \%$ \\
\hline 5 & Penggunaan bahasa yang santun & & & & & $\sqrt{ }$ & $100 \%$ \\
\hline \multicolumn{7}{|c|}{ Jumlah } & \\
\hline \multicolumn{8}{|c|}{ Aspek Tata bahasa } \\
\hline 1 & $\begin{array}{l}\text { Kesesuaian dengan kaidah Bahasa } \\
\text { Indonesia yang baik dan benar }\end{array}$ & & & & $\sqrt{ }$ & & $80 \%$ \\
\hline 2 & Ketepatan struktur kalimat & & & & $\sqrt{ }$ & & $80 \%$ \\
\hline
\end{tabular}




\begin{tabular}{|c|c|c|c|}
\hline No & Indikator & Skor Penilaian & $\%$ \\
\hline 3 & $\begin{array}{l}\text { Penggunaan bahasa secara efektif dan } \\
\text { efesien. }\end{array}$ & $\sqrt{1}$ & $80 \%$ \\
\hline 4 & Ketepatan penggunaan tanda baca. & $\sqrt{ }$ & $80 \%$ \\
\hline 5 & Diksi & $\sqrt{ }$ & $80 \%$ \\
\hline & Jumlah & 20 & \\
\hline & Jumlah aspek1 dan 2 & $24+20=44$ & \\
\hline
\end{tabular}

Berdasarkan hasil validasi ahli bahasa yang terdapat pada tabel 4.2, maka persentase tingkat kelayakan dapat dihitung menggunakan rumus sebagai berikut :

$$
\mathbf{P}=\frac{f}{N} \times 100 \%
$$

\section{Keterangan:}

$$
\begin{aligned}
& \mathrm{P}=\text { Angka persentase data angket } \\
& F=\text { Jumlah skor yang diperoleh } \\
& \mathrm{N}=\text { Jumlah skor maksimum } \\
& \mathbf{P}=\frac{44}{50} \times 100 \% \\
& \mathrm{P}=88 \%
\end{aligned}
$$

Dari perhitungan tersebut diperoleh data presentasi tingkat kelayakan bahan ajar dari segi bahasa sebesar $88 \%$. Berdasarkan tabel interpresentasi kelayakan, bahan ajar tematik berbasis nilai-nilai keislaman dinyatakan sangat layak dari segi bahasa, karena nilai validasi yang diperoleh dari ahli bahasa adalah $88 \%$, sehingga bahan ajar tersebut siap digunakan untuk kegiatan pembelajaran, tetapi ada saran dan masukan tentang beberapa penulisan kata dan istilah yang kurang tepat untuk direvisi.

\section{Hasil Validasi Ahli Desain}

Validasi desain bertujuan untuk mengetahui ketepatan dan kemenarikan bahan ajar yang dikembangkan. Validasi desain dilakukan oleh Dr. H. Mundir, M.Pd. Beliau adalah seorang dosen Pascasarjana IAIN Jember. Penilaian ahli desain terdiri dari dua aspek, yaitu aspek desain sampul dan aspek desain isi buku. Aspek desain sampul terdiri dari 5 indikator dan aspek desain isi buku terdiri dari 7 indikator, sehingga kalau dijumlahkan terdiri dari 12 indikator dengan skor 1-5. Data hasil validasi ahli desain dapat dilihat pada tabel 4.3 berikut: 
Tabel 4.3

Hasil Validasi Ahli Desain

\begin{tabular}{|c|c|c|c|c|c|c|c|}
\hline \multirow{2}{*}{ No } & \multirow{2}{*}{ Indikator } & \multicolumn{5}{|c|}{ Skor Penilaian } & \multirow{2}{*}{$\%$} \\
\hline & & 1 & 2 & 3 & 4 & 5 & \\
\hline \multicolumn{8}{|c|}{ Aspek Desain Sampul } \\
\hline 1 & $\begin{array}{l}\text { Kemenarikan dan kejelasan desain } \\
\text { sampul buku }\end{array}$ & & & & & $\sqrt{ }$ & $100 \%$ \\
\hline 2 & $\begin{array}{l}\text { Kesesuaian gambar sampul buku } \\
\text { dengan tema }\end{array}$ & & & & & $\sqrt{ }$ & $100 \%$ \\
\hline 3 & $\begin{array}{l}\text { Kesesuaian penulisan judul, kurikulum } \\
2013 \text {, dan nama penulis pada sampul } \\
\text { buku }\end{array}$ & & & & $\sqrt{ }$ & & $80 \%$ \\
\hline 4 & $\begin{array}{l}\text { Kesesuaian pemilihan jenis dan ukuran } \\
\text { huruf pada sampul }\end{array}$ & & & & & $\sqrt{ }$ & $100 \%$ \\
\hline 5 & $\begin{array}{l}\text { Komposisi Tata letak (lay out) dan } \\
\text { template }\end{array}$ & & & & $\sqrt{ }$ & & $80 \%$ \\
\hline \multicolumn{2}{|r|}{ Jumlah } & \multicolumn{5}{|c|}{23} & \\
\hline \multicolumn{8}{|c|}{ Aspek Desain Isi Buku } \\
\hline 1 & $\begin{array}{l}\text { Penempatan unsur tata letak } \\
\text { konsistensi berdasarkan tata letak spasi, } \\
\text { judul, sub judul, pengetikan materi }\end{array}$ & & & & & $\sqrt{ }$ & $100 \%$ \\
\hline 2 & $\begin{array}{l}\text { Kesesuaian dan kejelasan gambar } \\
\text { dengan konteksnya. }\end{array}$ & & & & & $\sqrt{ }$ & $100 \%$ \\
\hline 3 & $\begin{array}{l}\text { Ketepatan penempatan dan ukuran } \\
\text { gambar }\end{array}$ & & & & $\sqrt{ }$ & & $80 \%$ \\
\hline 4 & Keterpaduan gambar dengan topik & & & & $\sqrt{ }$ & & $80 \%$ \\
\hline 5 & $\begin{array}{l}\text { Pemilihan dan kesesuaian warna } \\
\text { gambar dan background }\end{array}$ & & & & & $\sqrt{ }$ & $100 \%$ \\
\hline 6 & $\begin{array}{l}\text { Ketepatan pemilihan jenis dan ukuran } \\
\text { huruf. }\end{array}$ & & & & $\sqrt{ }$ & & $80 \%$ \\
\hline 7 & $\begin{array}{l}\text { Kemenarikan keseluruhan tampilan } \\
\text { produk }\end{array}$ & & & & & $\sqrt{ }$ & $100 \%$ \\
\hline \multicolumn{2}{|r|}{ Jumlah } & \multicolumn{5}{|c|}{32} & \\
\hline & Jumlah aspek 1 dan 2 & \multicolumn{5}{|c|}{$23+32=55$} & \\
\hline
\end{tabular}

Berdasarkan hasil validasi ahli materi yang terdapat pada tabel 4.3, maka persentase tingkat kelayakan dapat dihitung menggunakan rumus sebagai berikut:

$\mathbf{P}=\frac{f}{N} \times 100 \%$

\section{Keterangan:}

$\mathrm{P}=$ Angka persentase data angket

$F=$ Jumlah skor yang diperoleh

$\mathrm{N}=$ Jumlah skor maksimum

$\mathbf{P}=\frac{55}{60} \times 100 \%$

$\mathrm{P}=91,67 \%$ 
Dari perhitungan tersebut diperoleh data presentasi tingkat kelayakan bahan ajar dari segi desain sebesar 91,67\%. Berdasarkan tabel interpresentasi kelayakan, bahan ajar tematik berbasis nilai-nilai keislaman dinyatakan sangat layak dari segi desain, karena nilai validasi yang diperoleh dari ahli desain adalah 91,67\%, sehingga bahan ajar tersebut siap digunakan untuk kegiatan pembelajaran. Saran dari ahli desain bahwa kertas yang digunakan terlalu baik kalau untuk buku peserta didik, karena kertas yang digunakan tidak bisa ditulisi menggunakan bolpoin, padahal peserta didik banyak mengerjakan tugas langsung di buku peserta didik.Selain penyajian data hasil validasi dari validator, data tersebut direkapitulasi untuk mengetahui tingkat kelayakan bahan ajar secara keseluruhan dari ketiga validator Rekapitulasi tingkat kelayakan produk terdapat dalam tabel 4.4 berikut:

Tabel 4.4

Rekapitulasi Hasil Uji Validasi Ahli

\begin{tabular}{|c|c|c|}
\hline No & Validasi ahli & Hasil validasi \\
\hline 1 & Materi/isi & $89,41 \%$ \\
\hline 2 & Bahasa & $88 \%$ \\
\hline 3 & Desain & $91,67 \%$ \\
\hline \multicolumn{2}{|c|}{ Total perolehan } & $269,08 \%$ \\
\hline \multicolumn{2}{|c|}{ Rata-rata } & $89,69 \%$ \\
\hline
\end{tabular}

Dari tabel 4.4 di atas, hasil rekapitulasi tingkat kelayakan produk dari ketiga validator rata-rata $89,69 \%$. Rata-rata tersebut menunjukkan bahwa "bahan ajar yang dikembangkan berada pada kriteria sangat layak untuk dipergunakan dalam kegiatan pembelajaran".

\section{Hasil Respon Peserta didik}

Untuk mengetahui seberapa menarik bahan ajar yang dikembangkan bagi peserta didik, maka peneliti perlu respon peserta didik tentang bahan ajar tersebut. Respon peserta didik diperoleh dari angket yang dibagikan kepada peserta didik, kemudian peneliti mengolah data dari hasil respon peserta didik tersebut. 
Berikut rekapitulasi respon peserta didik yang kami sajikan dalam tabel 4.5.

Tabel 4.5

Rekapitulasi Respon Peserta didik

\begin{tabular}{|c|c|c|c|}
\hline No & Nama Peserta didik & Jumlah skor & $\%$ \\
\hline 1 & M. Daffa Mahardika & 32 & $91,4 \%$ \\
\hline 2 & Maulidiana Faizah & 28 & $80 \%$ \\
\hline 3 & Mu'tashim Billah Al-Q & 32 & $91,4 \%$ \\
\hline 4 & Manda Aulia A & 35 & $100 \%$ \\
\hline 5 & Nur Hikmah Indah Sari & 33 & $94,3 \%$ \\
\hline 6 & Navisatul Qulubi & 31 & $88,6 \%$ \\
\hline 7 & Nafisah Laila Octavia & 25 & $71,4 \%$ \\
\hline 8 & Niken Larasati & 34 & $97,1 \%$ \\
\hline 9 & Nilta Husnayaini & 30 & $85,7 \%$ \\
\hline 10 & Regina Ayu Margantari & 29 & $82,9 \%$ \\
\hline 11 & Rafael Ahmad Ferdisha & 32 & $91,4 \%$ \\
\hline 12 & Salwah Heldi Salsabila & 32 & $91,4 \%$ \\
\hline 13 & Satria Arjuna & 31 & $88,6 \%$ \\
\hline 14 & Septiana Panca Marisca & 29 & $82,9 \%$ \\
\hline 15 & Siti Amelia & 31 & $88,6 \%$ \\
\hline 16 & Siti Imas Aulia Susanti & 35 & $100 \%$ \\
\hline 17 & Sanavisatus Sa'diyah & 30 & $85,7 \%$ \\
\hline 18 & Suhaeifa Heriyantika & 29 & $82,9 \%$ \\
\hline 19 & Umi Qur'aini Ramafani & 33 & $94,3 \%$ \\
\hline 20 & Wike Ayu Widiastutik & 33 & $94,3 \%$ \\
\hline 21 & Wahyu Rizqiyanto & 27 & $77,1 \%$ \\
\hline 22 & Yuni Sarah Ababil & 33 & $94,3 \%$ \\
\hline 23 & Hana Talita & 26 & $74,3 \%$ \\
\hline 24 & Danial Tazakka Prabowo & 32 & $91,4 \%$ \\
\hline 25 & Zaki Abdillah & 32 & $91,4 \%$ \\
\hline 26 & M. Edo Adi Prasetyo & 31 & $88,6 \%$ \\
\hline \multicolumn{2}{|r|}{ Jumlah } & 805 & $88,5 \%$ \\
\hline
\end{tabular}

Dari tabel tersebut, data yang diperoleh dari angket yang diberikan kepada peserta didik dalam menggunakan bahan ajar dapat diolah dengan menggunakan rumus: 


$$
\mathbf{M}=\frac{\sum x}{\sum x m} \times 100 \%{ }^{13}
$$

\section{Keterangan:}

$$
\begin{aligned}
& \mathrm{M}=\text { presentase kemenarikan } \\
& \sum x=\text { Jumlah keseluruhan jawaban peserta didik } \\
& \sum \mathrm{xm}=\text { Jumlah keseluruhan skor ideal dalam satu item } \\
& 100 \%=\text { konstanta }
\end{aligned}
$$

Jumlah kesuluruhan jawaban peserta didik diperoleh dari skor pernyataan dikalikan dengan jumlah respon peserta didik yaitu 805, sedangkan jumlah keseluruhan skor ideal didapat dari skor maksimal pernyataan dikalikan jumlah responden dikalikan jumlah pernyataan, yaitu $5 \times 26 \times 7=910$.

Jadi presentase kemenarikan bahan ajar sebagai berikut:

$$
\begin{aligned}
& \mathbf{M}=\frac{805}{910} \times 100 \% \\
& \mathbf{M}=88,5 \%
\end{aligned}
$$

Berdasarkan paparan tabel kemenarikan bahan ajar, tingkat kemenarikan bahan ajar berada pada kriteria sangat menarik, karena presentasenya $88,5 \%$, sehingga produknya bisa digunakan tanpa revisi.

\section{Analisis Data Uji Coba}

Penyajian Hasil perolehan data pre-test

Penyajian dari hasil pre-test peserta didik kelas VI MIN 2 Jember sebelum menggunakan bahan ajar yang dikembangkan dapat dilihat pada tabal 4.7.

Tabel 4.7

Hasil Nilai Pre-Test Hasil Uji Coba Lapangan

\begin{tabular}{|l|l|c|c|}
\hline No & \multicolumn{1}{|c|}{ Nama Peserta didik } & Skor & Keterangan \\
\hline 1 & M. Daffa Mahardika & 66 & Tidak tuntas \\
\hline 2 & Maulidiana Faizah & 68 & Tidak tuntas \\
\hline 3 & Mu'tashim Billah Al-Q & 56 & Tidak tuntas \\
\hline 4 & Manda Aulia A & 76 & Tuntas \\
\hline 5 & Nur Hikmah Indah Sari & 32 & Tidak tuntas \\
\hline 6 & Navisatul Qulubi & 74 & Tuntas \\
\hline
\end{tabular}

\footnotetext{
${ }^{13}$ Sugiono, Metode Penelitian Pendidikan Kuantitatif $R \& D$, (Bandung: Al Fabeta 2011), 299
} 


\begin{tabular}{|l|l|c|c|}
\hline No & \multicolumn{1}{|c|}{ Nama Peserta didik } & Skor & Keterangan \\
\hline 7 & Nafisah Laila Octavia & 70 & Tuntas \\
\hline 8 & Niken Larasati & 88 & Tuntas \\
\hline 9 & Nilta Husnayaini & 88 & Tuntas \\
\hline 10 & Regina Ayu Margantari & 60 & Tidak tuntas \\
\hline 11 & Rafael Ahmad Ferdisha & 56 & Tidak tuntas \\
\hline 12 & Salwah Heldi Salsabila & 68 & Tidak tuntas \\
\hline 13 & Satria Arjuna & 65 & Tidak tuntas \\
\hline 14 & Septiana Panca Marisca & 52 & Tidak tuntas \\
\hline 15 & Siti Amelia & 56 & Tidak tuntas \\
\hline 16 & Siti Imas Aulia Susanti & 72 & Tuntas \\
\hline 17 & navisatus Sa'diyah & 16 & Tidak tuntas \\
\hline 18 & Suhaeifa Heriyantika & 64 & Tidak tuntas \\
\hline 19 & Umi Qur'aini Ramafani & 76 & Tuntas \\
\hline 20 & Wike Ayu Widiastutik & 68 & Tidak tuntas \\
\hline 21 & Wahyu Rizqiyanto & 48 & Tidak tuntas \\
\hline 22 & Yuni Sarah Ababil & 80 & Tuntas \\
\hline 23 & Hana Talita & 68 & Tidak tuntas \\
\hline 24 & Danial Tazakka Prabowo & 66 & Tidak tuntas \\
\hline 25 & Zaki Abdillah & 64 & Tidak tuntas \\
\hline 26 & M. Edo Adi Prasetyo & 24 & Tidak tuntas \\
\hline
\end{tabular}

Dari data hasil pre-test tersebut diketahui bahwa peserta didik yang tuntas mencapai: $\frac{8}{26}$ x $100 \%=30,77 \%$, sedangkan peserta didik yang tidak tuntas adalah: $\frac{18}{26} \times 100 \%=69,23 \%$.

Hasil perolehan data post-test

Penyajian dari post-test hasil uji coba lapangan setelah peserta didik menggunakan bahan ajar yang dikembangkan oleh peneliti terdapat pada tabel 4.8.

Tabel 4.8

Hasil Nilai Post-Test Hasil Uji Coba Lapangan

\begin{tabular}{|l|l|c|c|}
\hline No & \multicolumn{1}{|c|}{ Nama Peserta didik } & Skor & Keterangan \\
\hline 1 & M. Daffa Mahardika & 84 & Tuntas \\
\hline 2 & Maulidiana Faizah & 76 & Tuntas \\
\hline 3 & Mu'tashim Billah Al-Q & 78 & Tuntas \\
\hline 4 & Manda Aulia A & 92 & Tuntas \\
\hline 5 & Nur Hikmah Indah Sari & 56 & Tidak Tuntas \\
\hline
\end{tabular}




\begin{tabular}{|l|l|c|c|}
\hline 6 & Navisatul Qulubi & 88 & Tuntas \\
\hline 7 & Nafisah Laila Octavia & 88 & Tuntas \\
\hline 8 & Niken Larasati & 92 & Tuntas \\
\hline 9 & Nilta Husnayaini & 96 & Tuntas \\
\hline 10 & Regina Ayu Margantari & 96 & Tuntas \\
\hline 11 & Rafael Ahmad Ferdisha & 68 & Tidak Tuntas \\
\hline 12 & Salwah Heldi Salsabila & 88 & Tuntas \\
\hline 13 & Satria Arjuna & 84 & Tuntas \\
\hline 14 & Septiana Panca Marisca & 82 & Tuntas \\
\hline 15 & Siti Amelia & 84 & Tuntas \\
\hline 16 & Siti Imas Aulia Susanti & 88 & Tuntas \\
\hline 17 & navisatus Sa'diyah & 54 & Tidak Tuntas \\
\hline 18 & Suhaeifa Heriyantika & 84 & Tuntas \\
\hline 19 & Umi Qur'aini Ramafani & 84 & Tuntas \\
\hline 20 & Wike Ayu Widiastutik & 68 & Tidak Tuntas \\
\hline 21 & Wahyu Rizqiyanto & 56 & Tidak Tuntas \\
\hline 22 & Yuni Sarah Ababil & 88 & Tuntas \\
\hline 23 & Hana Talita & 96 & Tuntas \\
\hline 24 & Danial Tazakka Prabowo & 96 & Tuntas \\
\hline 25 & Zaki Abdillah & 88 & Tuntas \\
\hline 26 & M. Edo Adi Prasetyo & 44 & Tidak Tuntas \\
\hline
\end{tabular}

Dari data hasil post-test tersebut diketahui bahwa peserta didik yang tuntas mencapai:

$$
\begin{aligned}
& \frac{20}{26} \times 100 \%=76,92 \%, \text { sedangkan peserta didik yang tidak tuntas } \\
& \text { adalah: } \frac{6}{26} \times 100 \%=23,08 \%
\end{aligned}
$$

Hasil perolehan data pre-test dan post- test

Hasil penilain dari pre-test dan post-test digunakan untuk mengetahui keefektifan bahan ajar yang dikembangkan. Dari hasil tersebut akan dibandingkan, sehingga dari hasil perbandingan tersebut akan diketahui tingkat keefektifan bahan ajar yang dikembangkan. Analisis data untuk mengetahui efektifitas bahan ajar menggunakan uji-t untuk membuktikan signifikasi perbedaan antara pre-test dan post-test menggunakan t-test paired two simple for means dengan rumus sebagai berikut: ${ }^{14}$

\footnotetext{
${ }^{14}$ Sugiono. Metode Penelitian Administrasi, ( Bandung: Alfabeta. 2013), 107
} 


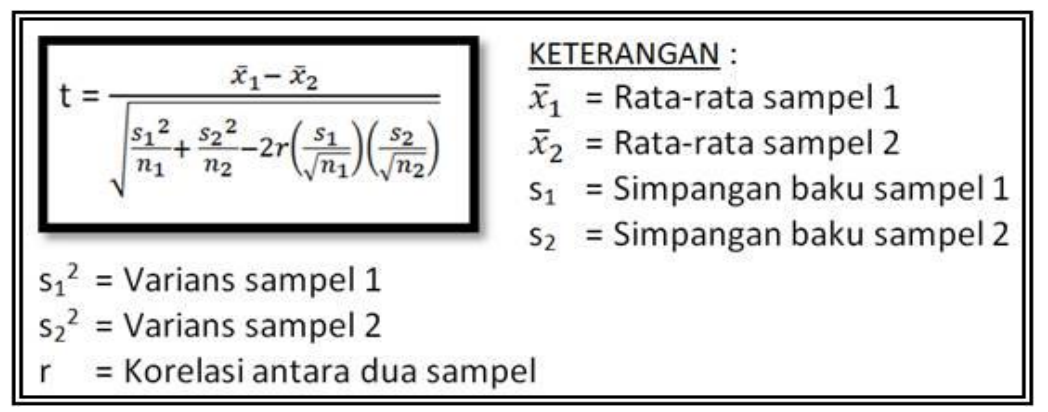

Perolehannilai dari hasil pre-test dan post-test dari bahan ajar terdapat pada tabel 4.9.

Tabel 4.9

Hasil Nilai Pre-Test dan Post-Test Hasil Uji Coba Lapangan

\begin{tabular}{|c|l|c|c|}
\hline No & Nama Peserta didik & Pre-Test & Post-Test \\
\hline 1 & M. Daffa Mahardika & 66 & 84 \\
\hline 2 & Maulidiana Faizah & 68 & 76 \\
\hline 3 & Mu’tashim Billah Al-Q & 56 & 78 \\
\hline 4 & Manda Aulia A & 76 & 92 \\
\hline 5 & Nur Hikmah Indah Sari & 32 & 56 \\
\hline 6 & Navisatul Qulubi & 74 & 88 \\
\hline 7 & Nafisah Laila Octavia & 70 & 88 \\
\hline 8 & Niken Larasati & 88 & 92 \\
\hline 9 & Nilta Husnayaini & 88 & 96 \\
\hline 10 & Regina Ayu Margantari & 60 & 96 \\
\hline 11 & Rafael Ahmad Ferdisha & 56 & 68 \\
\hline 12 & Salwah Heldi Salsabila & 68 & 88 \\
\hline 13 & Satria Arjuna & 65 & 84 \\
\hline 14 & Septiana Panca Marisca & 52 & 82 \\
\hline 15 & Siti Amelia & 56 & 84 \\
\hline 16 & Siti Imas Aulia Susanti & 72 & 88 \\
\hline 17 & Savinatus Sa'diyah & 16 & 54 \\
\hline 18 & Suhaeifa Heriyantika & 64 & 84 \\
\hline 19 & Umi Qur'aini Ramafani & 76 & 84 \\
\hline 20 & Wike Ayu Widiastutik & 68 & 68 \\
\hline 21 & Wahyu Rizqiyanto & 48 & 56 \\
\hline 221 & Yuni Sarah Ababil & 80 & 88 \\
\hline 23 & Hana Talita & 68 & 96 \\
\hline 24 & Danial Tazakka Prabowo & 66 & \\
\hline & & & 96 \\
\hline
\end{tabular}




\begin{tabular}{|l|l|l|l|}
\hline 25 & Zaki Abdillah & 64 & 88 \\
\hline 26 & M. Edo Adi Prasetyo & 24 & 44 \\
\hline
\end{tabular}

Dari pengolahan data hasil post-test dan pre-test tersebut, kemudian data diolah dengan t-test menggunakan aplikasi SPSS, dengan hasil yang dapat dilihat pada tabel 3.10

Tabel 4.10

Uji t-Test Paired Two Simple for Mean dengan SPSS

\begin{tabular}{|l|r|r|}
\hline \multicolumn{1}{|c|}{ Mean } & \multicolumn{1}{c|}{ Variable 1 } & \multicolumn{1}{c|}{ Variable 2 } \\
\hline Variance & 62,34615385 & \multicolumn{1}{c|}{80,69230769} \\
\hline Observations & 297,3553846 & 207,9815385 \\
\hline Pearson Correlation & 26 & \\
\hline Hypothesized Mean Difference & 0,823815011 \\
\hline Df & 0 & \\
\hline $\mathrm{t}$ Stat & $-9,567825426$ \\
\hline $\mathrm{P}(\mathrm{T}<=\mathrm{t})$ one-tail & $3,88055 \mathrm{E}-10$ \\
\hline $\mathrm{t}$ Critical one-tail & 1,708140761 & \\
\hline $\mathrm{P}(\mathrm{T}<=\mathrm{t})$ two-tail & $7,7611 \mathrm{E}-10$ & \\
\hline $\mathrm{t}$ Critical two-tail & 2,055538553 \\
\hline
\end{tabular}

Berdasarkan tabel " Pairet simple Test " diperoleh t-hitung -9,568 atau dimaknai positif yaitu 9,568 , sedangkan $\mathrm{t}$ table 2,0556 . Sehingga diperoleh $\mathrm{t}$ hitung > t tabel ( 9,568 > 2,0556 ), maka Ho ditolak dan Ha diterima. Berdasarkan hasil uji coba lapangan dapat disimpulkan bahwa bahan ajar Tematik Berbasis Nilai-nilai Keislaman Kelas VI Tema 7 yang dikembangkan oleh peneliti efektif untuk digunakan.

\section{Revisi Produk}

Berdasarkan kesimpulan dari analisis data menunjukkan bahwa setelah diadakan uji coba bahan ajar dengan model Borg \& Gall, validator mater/isi, validator bahasa, dan validator desain menunjukkan bahwa bahan ajar tematik berbasis nilai-nilai keislaman sangat efektif dan menarik, namun peneliti masih merevisi sebagian kecil sesuai saran yang diberikan oleh para validator. Revisi produk dilakukan pada: 
1. Sampul, gambar tokoh pada sampul yang sebelumnya ada gambar Bung Karno dan Wali Songo, kemudian direvisi gambar Bung Karno dihapus, warna sampul juga diubah semakin simpel, gambar karikatur juga dihapus, dan tulisan nama penulis, ditata kembali sesuai saran dari penguji, gelar penulis yang sebelumnya ada kemudian dihapus, serta warna dari tulisan pada sampul juga disesuaikan. Perbedaan sebelum revisi dan sesudah revisi bisa dilihat pada gambar 4.1

\section{Gambar 4.1 Revisi Sampul}

Sebelum

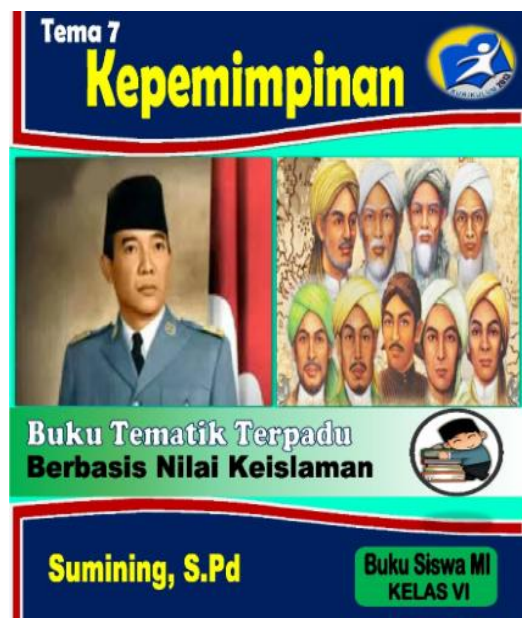

Sesudah Rvisi

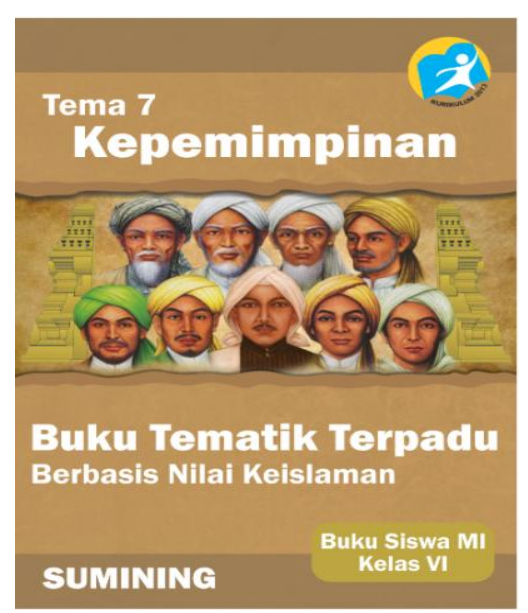

2. Kesalahan penulisan di halaman depan, yaitu pada halaman keterangan tentang buku peserta didik. Penulisan "Tentang Buku Peserta didik", yang seharusnya "Tentang Buku Peserta didik". Penulisan "panduan", seharusnya " panduan ". Selain di halaman depan, terdapat juga beberapa kesalahan ketik yang ada di dalam materi. Berikut contoh revisi atau perbaikan dari kesalahan penulisan.

3. Petunjuk penggunaan buku yang sebelumnya tidak ada, setelah mendapat saran dan masukan dari penguji bahwa petunjuk penggunaan buku penting dicantumkan karena akan memudahkan peserta didik atau guru menggunakan buku tersebut. Kemudian penulis merevisi bahan ajar yang dikembangkan diberi petunjuk penggunaan buku. 
4. Peta konsep yang sebelumnya tidak jelas garis yang menunjukkan pengelompokkan atau garis yang menunjukkan sistematika. Kemudian peta konsep direvisi sesuai petunjuk dari dosen pembimbing.

5. Peta konsep pada masing-masing sub tema, diperbaiki dengan langsung formatnya seperti pada peta konsep tema, karena peta konsep subtema merupakan potongan dari peta konsep tema, jadi berdasarkan saran para penguji sebaiknya formatnya jangan dirubah supaya tidak menimbulkan persepsi yang berbeda dalam memahami gambaran materi yang terdapat pada masing-masing subtema.

6. Jenis huruf yang sebelumnya Comic Sans MS diganti menjadi Arial karena jenis huruf Comic Sans MS termasuk dalam jenis sans-serif yang cocok untuk peserta didik kelas rendah yaitu kelas I dan II. Sedangkan Arial merupakan huruf jenis serif yang cocok untuk peserta didik kelas tinggi yaitu kelas III sampai kelas VI, bahkan untuk peserta didik jenjang yang lebih tinggi.

Dari beberapa revisi tersebut, bahan ajar yang dikembangkan menjadi lebih sempurna dan siap digunakan sebagai bahan ajar dalam kegiatan pembelajaran di Madrasah Ibtidaiyah

\section{SIMPULAN}

Hasil peneitian tentang buku ajar peserta didik berbasis nilai-nilai keislaman untuk kelas VI tema 7 di MIN 2 Jember dari hasil uji validasi tersebut rata-rata menghasilkan $88,79 \%$ dengan kriteria bahwa buku tersebut sangat layak untuk digunakan dalam pembelajaran. Dari segi kemenarikan, buku ini sangat menarik untuk digunakan pada peserta didik, hal ini berdasarkan dari hasil data angket yang diberikan kepada peserta didik dengan rata-rata $88,24 \%$ dengan kualifikasi sangat menarik. Sedangkan dari hasil pre-test dan pos-test berdasarkan uji t hitung yang menunjukan lebih besar dari t tabel, berarti buku tersebut efektif untuk digunakan dalam pembelajaran. 


\section{DAFTAR PUSTAKA}

Arifin, Bey. Tarjamah Sunan Abi Daud. Semarang: Asy Syifa,tt.

Hindanah, Wawancara, Jember 4 September 2019.

Kementrian Agama RI. Al-Qur"an dan Tafsirnya Jilid VII, 19-20- 21. Jakarta: Lentera Abadi, 2010.

Majid, Abdul. Pembelajaran Tematik Terpadu. Bandung: Remaja Rosdakarya, 2017.

Mulyasa. Guru dalam Implememtasi Kurikulum 2013. (Bandung: PT Remaja Rosdakarya, 2013).

Prastowo, Andi. Pengembangan Bahan Ajar Tematik Tinjauan Teoritik dan Praktik. Jakarta: Kencana Prenadamedia Group, 2014.

Rusman. Pembelajaran Tematik Terpadu Teori, Praktik dan Penilaian. Jakarta: Raja Grafindo Persada, 2015.

Sugiono. Metode Penelitian Administrasi. Bandung: Alfabeta, 2013.

Sugiyono. Metode Penelitian dan Pengembangan Research And Development, Bandung: Alfabeta, 2015.

UU RI No. 20 Tahun 2003.Tentang Sistem Pendidikan Nasional. Jakarta: Sinar Grafika, 2013.

UUD 1945, Hasil Amandemen ke-IV Tahun 2002. Surakarta: Al-Hikmah, 2002.

Valerica Anghelachea \& Cristina Corina Ben. Integrated Teaching The New Curricular Design Of Pre-Primaryeducational System In Romania. ProcediaSocial and Behavioral Sciences, (2012), 51. 